Supplement of Nat. Hazards Earth Syst. Sci., 16, 2799-2822, 2016

http://www.nat-hazards-earth-syst-sci.net/16/2799/2016/

doi:10.5194/nhess-16-2799-2016-supplement

(C) Author(s) 2016. CC Attribution 3.0 License.

(c) (i)

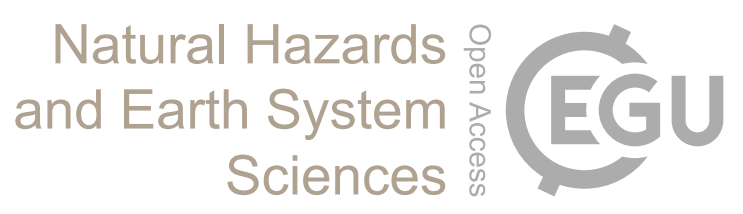

Supplement of

\title{
Typhoon Haiyan's sedimentary record in coastal environments of the Philippines and its palaeotempestological implications
}

D. Brill et al.

Correspondence to: Dominik Brill (brilld@uni-koeln.de)

The copyright of individual parts of the supplement might differ from the CC-BY 3.0 licence. 

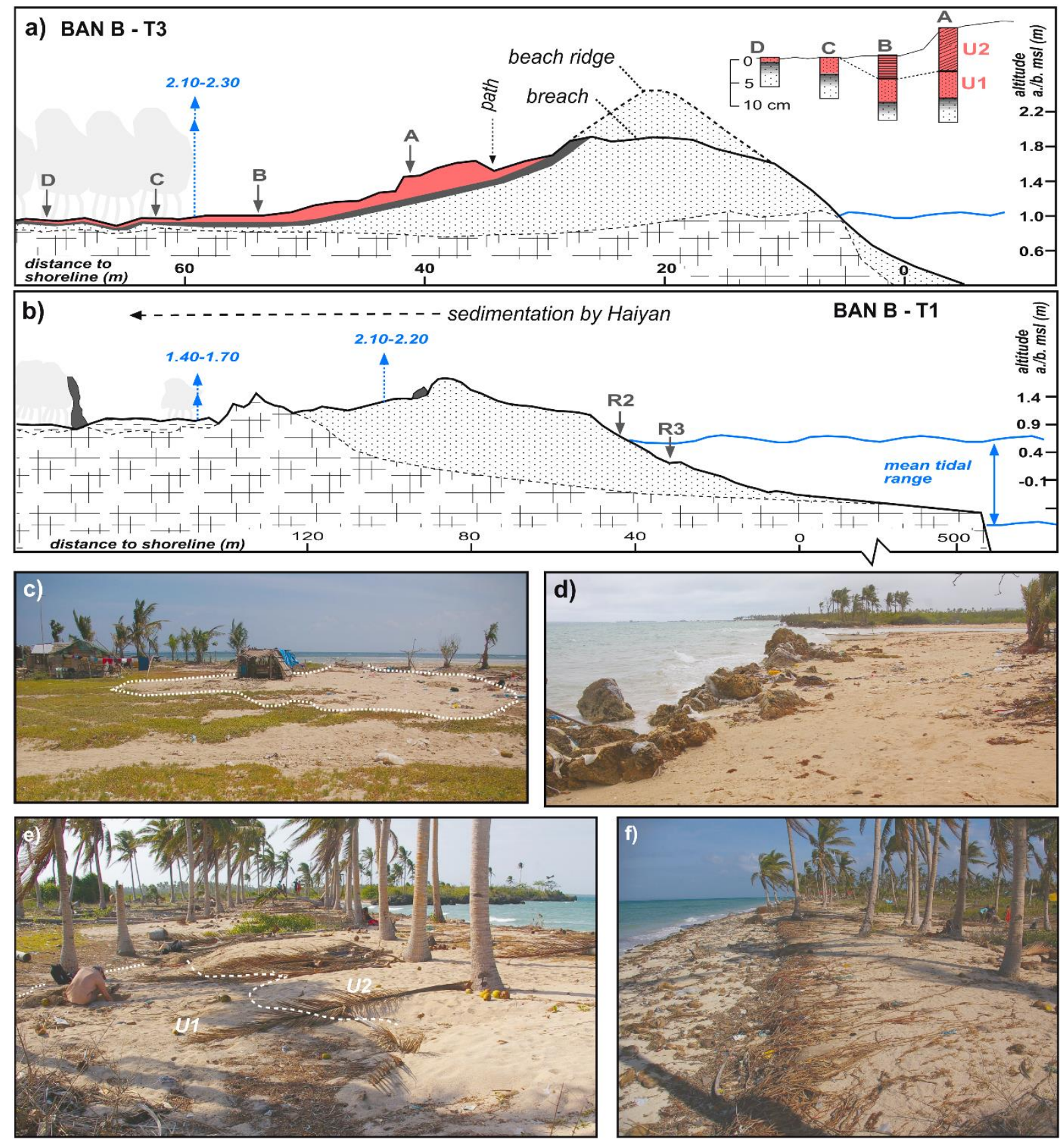

Fig. S1: Morphological and sedimentary characteristics of features created by Typhoon Haiyan at sites BAN A and BAN B. a) Cross section along transect 3 with locations of sampling sites. Directly behind a breach in the coastal barrier a landward thinning washover fan was formed by overtopping waves during Haiyan. The deposits consist of a massive sand sheet at the base (U1) and a laminated unit on top (U2). b) Cross section along transect 1 with location of reference samples from the modern beach $\left(R_{2}\right.$ and $\left.R_{3}\right)$. Flooding reached levels of nearly $2.5 \mathrm{~m}$ above msl, rapidly decreasing landward. c) Washover fan at BAN B shown from landward direction. d) Beach at BAN B. e) Washover fans at BAN A. Flat lobes of unit 1 (U1) are topped by steeper lobes with a smaller landward extent (U2). f) Beach at BAN A (date of all photographs 22-23 Feb 2014). 


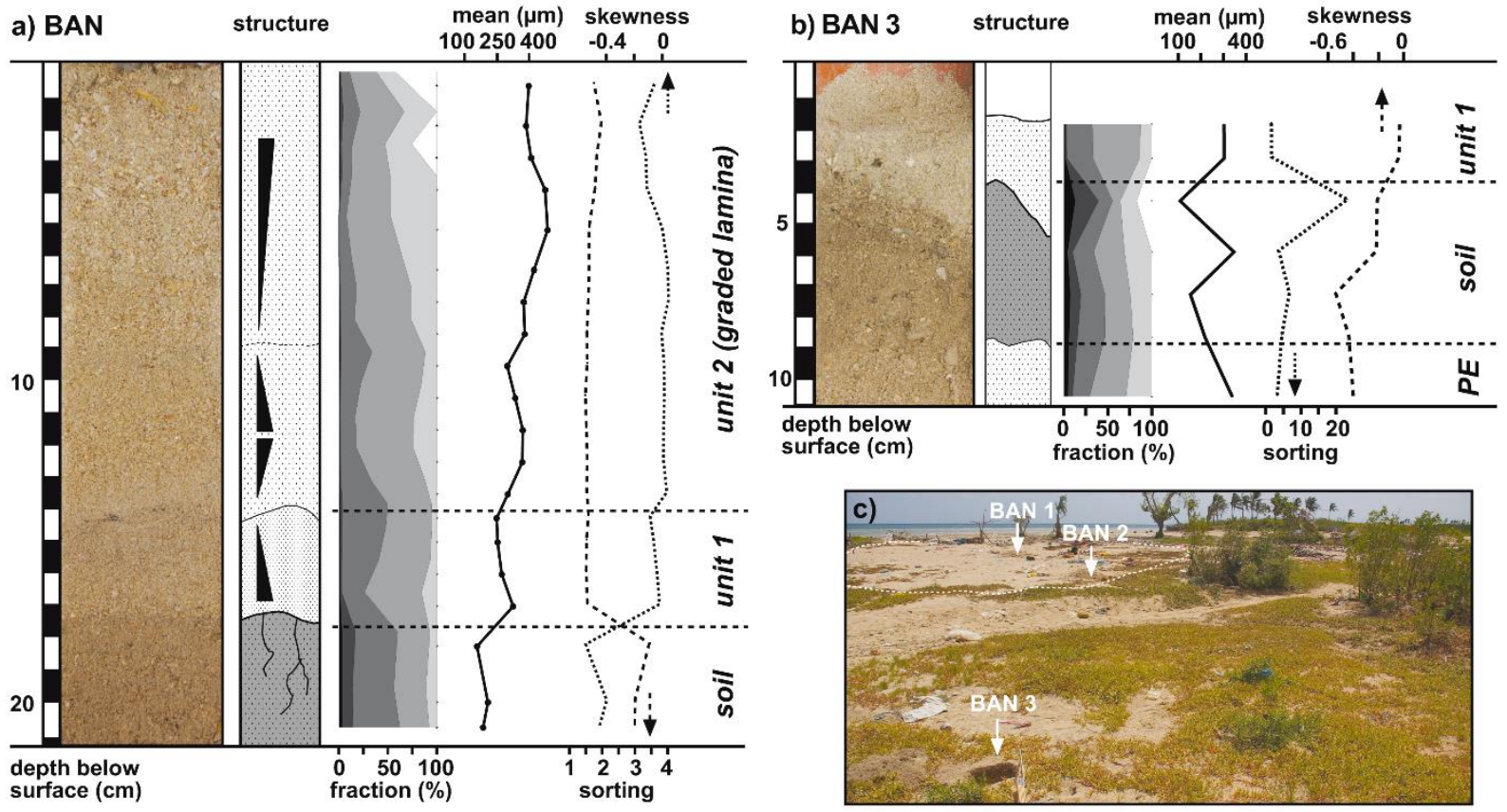

Fig. S2: Sedimentary succession of cores BAN 2 and BAN 3 at BAN B. a) While BAN 2 is composed of two distinct units, a massive or graded unit at the base (unit 1) and a laminated unit on top (unit 2), b) the storm layer in BAN 3 is formed by a single unstructured sedimentary unit only (unit 1). c) Photo at the bottom right shows view to the east along transect 2 (Fig. 11). 


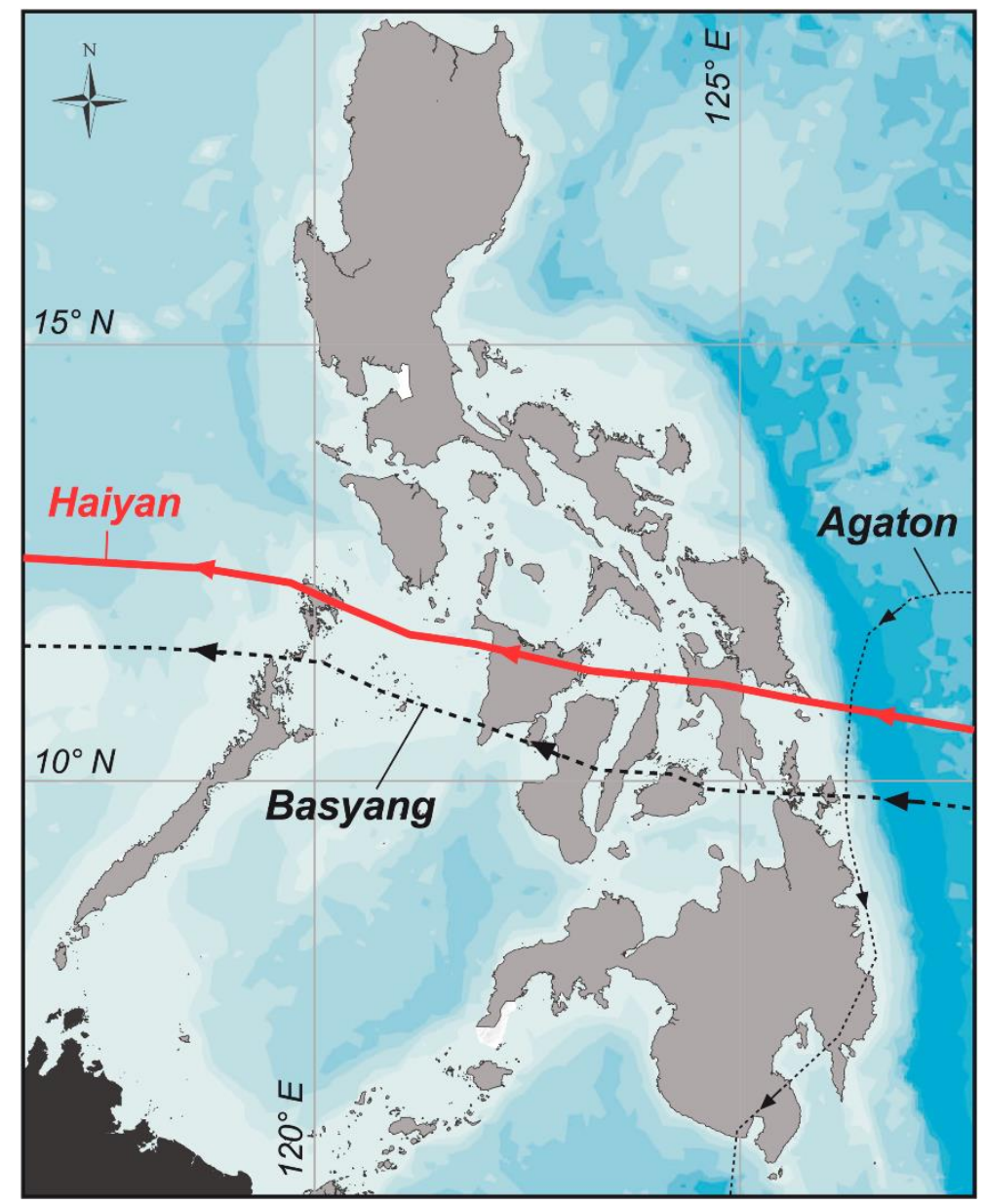

Fig. S3: Tracks of Typhoon Haiyan (NDRRMC 2014), tropical storm Basyang (PAGASA-DOST 2014a) and tropical depression Agaton (PAGASA-DOST 2014b) (map based on ESRI basemaps). While Agaton (January 19th, 2014) affected areas different from those affected by Haiyan, Basyang (February 1st, 2014) followed a similar, but more southern track. Nevertheless, the intensity of both Agaton (sustained wind speeds of up to $100 \mathrm{~km} / \mathrm{h}$ ) and Basyang (up to $120 \mathrm{~km} / \mathrm{h}$ ) was significantly smaller than that of Typhoon Haiyan $(315 \mathrm{~km} / \mathrm{h})($ PAGASA-DOST 2014). 


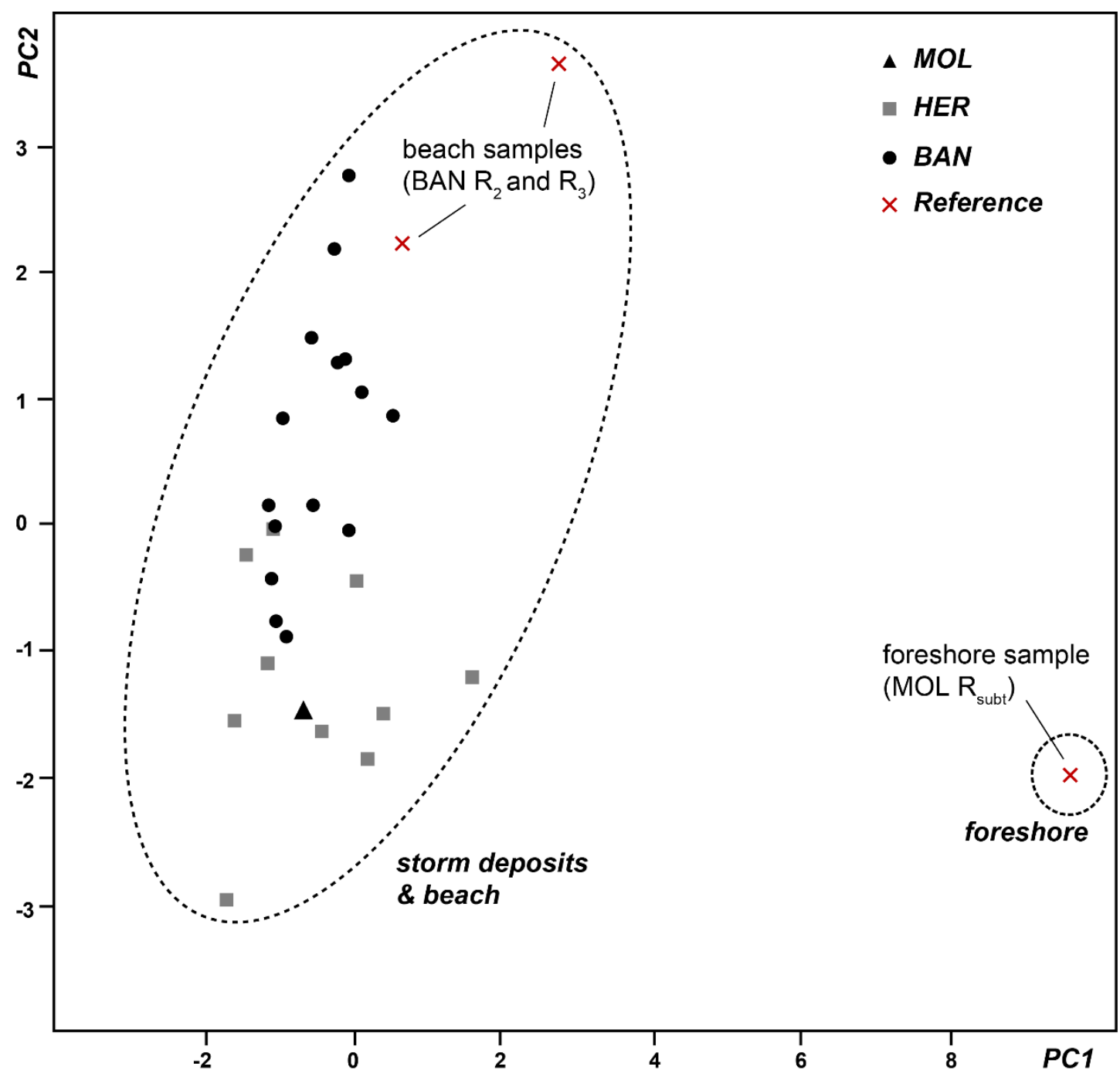

Fig. S4: PCA results on foraminifer data from all sites. Plotting of PC1 versus PC2 separates sediment from the foreshore on the one hand, and sediment from the beach and the storm deposits on the other. 
Tab. S1: Eyewitness accounts obtained from interviews at the investigated sites. Additional explanations in square brackets are added by the authors. E1-E8 are locations on Bantayan as marked on Figure 1.

\begin{tabular}{|c|c|c|c|}
\hline Site & Location & Eyewitness & Observation \\
\hline \multirow[t]{2}{*}{ Hernani } & $\begin{array}{l}11.300139^{\circ} \mathrm{N} \\
125.602389^{\circ} \mathrm{E}\end{array}$ & $\begin{array}{l}\text { local } \\
\text { resident }\end{array}$ & $\begin{array}{l}\text { - inundation reached slope of hill with school building } \\
\text { of barangay Batang [260 m inland] } \\
\text { - onland flood level in barangay up to } 9 \mathrm{~m} \text { without } \\
\text { reaching top of hill with school [12 } \mathrm{m} \text { a.s.l.] }\end{array}$ \\
\hline & $\begin{array}{l}11.321244^{\circ} \mathrm{N} \\
125.615472^{\circ} \mathrm{E}\end{array}$ & $\begin{array}{l}\text { local } \\
\text { resident }\end{array}$ & $\begin{array}{l}\text { - two storms between Haiyan and field survey [Agaton } \\
\text { and Basyang] that caused no significant inundation }\end{array}$ \\
\hline \multirow[t]{2}{*}{$\begin{array}{l}\text { Carbin } \\
\text { Reef }\end{array}$} & \multirow[t]{2}{*}{$\begin{array}{l}10.978228^{\circ} \mathrm{N} \\
123.464416^{\circ} \mathrm{E}\end{array}$} & $\begin{array}{l}\text { Guard of } \\
\text { Sagay } \\
\text { Marine } \\
\text { Reserve }\end{array}$ & $\begin{array}{l}\text { - sandy core of the island was completely flooded } \\
\text { - strong waves came from changing directions }\end{array}$ \\
\hline & & fisherman & - coral rubble ridge did not exist prior to Yolanda \\
\hline Suyac & $\begin{array}{l}10.948417^{\circ} \mathrm{N} \\
123.455577^{\circ} \mathrm{E}\end{array}$ & $\begin{array}{l}\text { local } \\
\text { resident }\end{array}$ & $\begin{array}{l}\text { - destruction of seawalls and movement of wall blocks } \\
\text { by Yolanda } \\
\text { - gradual change of wind and wave direction from } \\
\text { NNW to WSW (strongest waves) }\end{array}$ \\
\hline \multirow{7}{*}{ Bantayan } & $\begin{aligned} & \mathrm{E} 1: 11.167167^{\circ} \mathrm{N} \\
& 123.803139^{\circ} \mathrm{E}\end{aligned}$ & $\begin{array}{l}\text { local } \\
\text { resident }\end{array}$ & $\begin{array}{l}\text { - flooding reached only about } 30 \mathrm{~m} \text { landward of the } \\
\text { barrier to the first line of houses } \\
\text { - only a few cm of sand at the seaward side of houses }\end{array}$ \\
\hline & $\begin{aligned} & \mathrm{E} 2: 11.172222^{\circ} \mathrm{N} \\
& 123.800389^{\circ} \mathrm{E}\end{aligned}$ & $\begin{array}{l}\text { local } \\
\text { resident }\end{array}$ & $\begin{array}{l}\text { - flooding reached only about } 30 \mathrm{~m} \text { landward of the } \\
\text { barrier to the first line of houses } \\
\text { - a } 8 \mathrm{~m} \text { long boat was washed over the barrier } \\
\text { - waves during Yolanda were so high that people } \\
\text { could not see the island } 2.5 \mathrm{~km} \text { offshore anymore } \\
\text { [Cabulauan Island] }\end{array}$ \\
\hline & $\begin{array}{r}\text { BAN A: } 11.177550^{\circ} \mathrm{N} \\
123.793002^{\circ} \mathrm{E}\end{array}$ & $\begin{array}{l}\text { local } \\
\text { resident }\end{array}$ & $\begin{array}{l}\text { - strong erosion of the beach including basements of } \\
\text { exposed houses during Yolanda and Basyang (5-10 } \\
\mathrm{m} \text { in total) } \\
\text { - no significant onshore transport of sediment }\end{array}$ \\
\hline & $\begin{aligned} \mathrm{E} 5: & 11.185417^{\circ} \mathrm{N} \\
& 123.782528^{\circ} \mathrm{E}\end{aligned}$ & $\begin{array}{l}\text { local } \\
\text { resident }\end{array}$ & $\begin{array}{l}\text { - strong erosion of the beach }(5-10 \mathrm{~m}) \text { during } \\
\text { Basyang, while erosion by Yolanda was significantly } \\
\text { less severe }\end{array}$ \\
\hline & $\begin{array}{r}\text { E6: } 11.232917^{\circ} \mathrm{N}, \\
123.762361^{\circ} \mathrm{E}\end{array}$ & $\begin{array}{l}\text { local } \\
\text { resident }\end{array}$ & $\begin{array}{l}\text { - flooding by Yolanda reached } 100 \mathrm{~m} \text { inland [at a } \\
\text { funnel-shaped inlet] } \\
\text { - gradual change of wind direction from north to south } \\
\text { during passage of Yolanda } \\
\text { - no significant flooding by Basyang or Agaton }\end{array}$ \\
\hline & 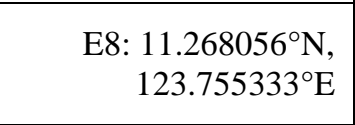 & $\begin{array}{l}\text { local } \\
\text { resident }\end{array}$ & $\begin{array}{l}\text { - destruction of houses and mangroves up to } 50 \mathrm{~m} \\
\text { inland by Yolanda } \\
\text { - no significant impact of Basyang or Agaton }\end{array}$ \\
\hline & 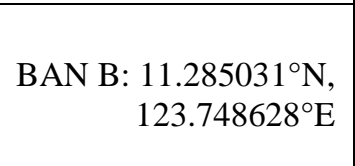 & $\begin{array}{l}\text { local } \\
\text { resident }\end{array}$ & $\begin{array}{l}\text { - flooding by Yolanda reached at least } 100 \mathrm{~m} \text { inland } \\
\text { and flow levels of } 1.5 \mathrm{~m} \text { a.s. in mangroves } \\
\text { - Yolanda strongest typhoon of last } 20 \text { years; Basyang } \\
\text { and Agaton caused no flooding behind the barrier }\end{array}$ \\
\hline
\end{tabular}




\section{References}

NDRRMC (2014): SitRep No. 107 Effects of Typhoon "YOLANDA" (HAIYAN) (March 14th, 2014), http://www.ndrrmc.gov.ph/attachments/article/1125/Update\%20Yolanda\%20Sitrep\%20107.pdf; Last access: 19.03.2014

PAGASA-DOST 2014a: Status Report tropical storm $\quad$ Basyang 2014. http://pagasa.dost.gov.ph/index.php/bulletin-archive/108-basyang-2014. Last access: 02/17/2015

PAGASA-DOST 2014b: Status Report tropical depression Agaton 2014. http://pagasa.dost.gov.ph/index.php/bulletin-archive/175-agaton-2014. Last access: 02/17/2015 